\title{
Bloghálózatok rejtett közössége
}

\section{Szerzői információ:}

\section{Zsigó Dávid}

2008-ban végzett a Budapesti Corvinus Egyetem Társadalomtudományi Karán és a Rajk László Szakkollégiumban. Diplomamunkájában az online közösségek és a bloghálózatok vizsgálatával foglalkozott. Döntéselméleti, majd virtuális közösségeket vizsgáló kutatásokban múködött közre, és részt vett a magyarországi Phare-program értékelésében. Jelenleg az Index Zrt. internetes divíziójának projektmenedzsere. Érdeklődési területei: az online közösségek változásai és a webalkalmazások gazdasági és kulturális hatásai.

E-mail: zsigodavid@gmail.com

Így hivatkozzon erre a cikkre:

Zsigó Dávid. „Bloghálózatok rejtett közössége”.

Információs Társadalom VIII, 4. szám (2008): 115-131.

A folyóiratban közölt müvek

a Creative Commons Nevezd meg! - Ne add el! - Így add tovább! 4.0

Nemzetközi Licenc feltételeinek megfelelően használhatók. 
Zsigó Dávid

\section{B loghálózatok rejtett közössége}

\section{Bevezetés}

Fél évvel ezelốtt a magyar online médiaipar egyik vezetôjével a blogszolgáltatók üzleti lehetôségeiról beszelgettünk. Akkori állítása szerint azért éri meg blogot üzemeltetni, mert a blogok köré online közösségek szerveződnek, melyeknek a tagjait már könnyedén át lehet terelni a profitábilis szolgáltatásokhoz, mint ahogy az korábban az Index fórumok esetében is történt. A blogok köré szervezôdô közösségek léte azonban nem volt nyilvánvaló számomra, így feltettem magamnak a kérdést: Valóban léteznek online közösségek a blogok körül?

Dolgozatomban arról a kutatásról adok számot, melynek során tizennégy zenei blog mintáján vizsgáltam, hogy létrejön-e hálózat az egyes blogok között, és ha igen, az milyen jellemzókkel írható le. Fó kérdésem az volt, hogy kialakul-e a virtuális közösség valamilyen formája a bloghálózat keretein belül. A kérdések megválaszolásához elôször a blogok közötti digitális kapcsolatokat és a bloggerek egymás blogjain megjelenó üzeneteit vizsgáltam, majd kérdőíves technikával feltérképeztem a mintában szereplő bloggerek közötti kapcsolati háló súrúségét, s végül mélyinterjúk segítségével igyekeztem megismerni a kapcsolatok valódi tartalmát és jelentôségét a résztvevók szempontjából.

\section{Online közösségek és kapcsolatok}

Az online közösségek számos eltérő meghatározása ismeretes, ám a számítógéppel közvetített kommunikáció (CMC) mindegyikben jelen van. Matzat értelmezése szerint egy online közösség olyan emberek csoportja, akik számítógépes eszközök segítségével kommunikálnak egymással, és ez a kommunikáció alapvetốen az egyének közös érdeklődése körül összpontosul (Matzat 2004). A közös érdeklődés, a közös célok és az elektronikus úton való kommunikáció más szerzốk felfogásában is megjelenik az online közösségek fó ismérveként (Dennis-Pootheri-Natarajan 1998, Figallo 1998). Ezek a szerzók csupán a közös érdeklốdést, a közös témát hangsúlyozzák, értelmezésükben az érzelmi háttér nem feltétlenül csoportképző ismérv. Ezzel szemben Rheingold értelmezésében fontos szempont az „érzelmi érintettség” és a „kapcsolat személyes jellege" is (Rheingold 1993).

A virtuális közösségek definiálásában megjelenik az a szempont is, hogy az adott személy milyen gyakorisággal vesz részt az adott közösség életében. Legtöbbször az egyének csatlakoznak egy közösséghez, majd rendszeresen látogatják azt (Hiltz-Wellman 1997), szélsőséges esetekben azonban kialakulhat a közösségtól való függőség is (Hiltz 1984). Habár azt illetốen még nem jött létre konszenzus, hogy milyen gyakoriságú részvétel tesz valakit egy közösség aktív tagjává, a leggyakrabban elfogadott nézet szerint a 
virtuális közösségek tagjai egymással „,rendszeresen” kapcsolatba lépó egyének (Smith 1999). Egy átfogó definíció a következóképpen határozza meg az online közösségek fogalmát: „közös érdeklődési körrel és szokásokkal rendelkezố emberek csoportja, akik szervezett keretek között, az internet segítségével rendszeresen és tartósan kommunikálnak egymással" (Ridings-Gefen-Arinze 2002, 273).

Az 1990-es években nagy érdeklődést keltő kutatási témává vált az a kérdés, hogy az online közösségek tagjai között mennyiben állnak fenn valós kapcsolatok. A probléma hátterében az a nézet áll, miszerint az internetes kapcsolatok a hagyományos kapcsolatoknál kisebb jelentôségúek. Ennek fó oka az, hogy az online világ a személyes érintkezés hiányában szenved. A hétköznapi életben a kommunikáció fontos elemei ugyanis a gesztikulálás, a mimika, a hanglejtés vagy a testbeszéd, az internetes kommunikáció során azonban ezeknek csupán a helyettesítối (az ún. emotikonok) jelennek meg. A kommunikációs korlátok leküzdésének eszköze lehet még a kedves, személyes kifejezések elhelyezése a szövegben, valamint az online kommunikáció kiegészítése hagyományos kommunikációs formákkal (Parks-Floyd 1996). Az online világban mindazonáltal -éppen e hiányosságok következtében - gyengébb kötelékek alakulnak ki az emberek között.

Wellman és Gulia kiemelik, hogy az online és offline kapcsolatokat nem lehet teljesen elkülönülten vizsgálni, hiszen az online kapcsolatok is mindennapjaink részét képezik (Wellman-Gulia 1999). Álláspontjuk szerint mind az online, mind az offline érintkezésnek, illetve mind a gyengébb, mind a szorosabb kapcsolatoknak megvan a maguk funkciója, tehát mindkét fajta kapcsolatok fenntartása és ápolása egyaránt fontos.

Sassenberg az online közösségek jellemzésekor a csoporthoz való tartozás érzését emeli ki (Sassenberg 2002). Peter Kollock vizsgálatai (Kollock 1999) arra az érdekes megállapításra vezettek, hogy az emberek olyan dolgokban is segítenek egymásnak online, amelyekben offline ezt nem vagy csak ellenszolgáltatás fejében tennék meg. Kollock felhívja továbbá a figyelmet Wellmann és Gulia (1999), valamint Rheingold (1993) tanulmányaira, melyek szerint azok, akik rendszeresen segítik a többieket, gyorsabb és több segítségre számíthatnak a csoporttól. Ezek a szerzók erôs normák és szankciók meglétének, illetve kimutatásának a lehetőségét is elénk tárják.

Ridings és Gefen arra a kérdésre keresték a választ, hogy az egyének miért csatlakoznak online közösségekhez (Ridings-Gefen-Arinze 2002). Korábbi tanulmányokra és elméletekre támaszkodva több lehetséges motivációs tényezốt is összegyújtöttek. Ilyen például az, hogy az egyén számára értékes információhoz lehet jutni egy-egy virtuális közösség keretein belül. További motiváló tényezó lehet az érzelmi támogatás, a csoporthoz való tartozás érzete, a személyes problémák megbeszélésének lehetôsége. Sokan azért csatlakoznak online közösségekhez, hogy ott barátokra, illetve hasonló érdeklődésú emberekre leljenek. Mások kikapcsolódásnak, szórakozásnak tekintik a virtuális közösségekben való részvételt.

A „hírnév” motivációs szerepével Daniel Stewart foglalkozik behatóan (Stewart 2005). A hírnév kérdésköre a jelen kutatás szempontjából is releváns, mivel az egyik hipotézis éppen erre épül. A „hírnév” az online közösségek esetében természetesen az adott közösségen belüli hírnevet jelenti, fakadhat azonban abból is, hogy a közösség tagjai az offline világban is kapcsolatban állnak egymással, és az offline státusukat, mondjuk úgy, magukkal viszik az online közösségbe. 
Az internethasználatnak a társas kapcsolatokra gyakorolt hatásaival viszonylag bôséges irodalom foglalkozik. Parks és Floyd az online kapcsolatok vizsgálatakor két szembenálló felfogást mutatnak be (Parks-Floyd 1996). Az egyik álláspont szerint az internetes kapcsolatok felszínesek, személytelenek és gyakran ellenségesek. Azok a szerzók, akik így gondolkodnak, azt feltételezik, hogy a virtuális világban csak , látszatközösségek” jönnek létre (Berry 1993). Elsốsorban a kilencvenes évek elején fogalmazódtak meg hasonló vélemények, amelyeket leginkább arra alapoztak, hogy az online anonimitás nagyobb teret enged az agressziónak, az ellenséges vagy normasértô viselkedésnek. Az ezzel ellentétes álláspont szerint az internet lehetôséget nyújt új személyes kapcsolatok és új közösségek kialakítására. E szerint a felfogás szerint (McKennaGreen-Gleason 2002) az anonimitás, az elszigeteltség és a sok hasonló érdeklődésú ember virtuális jelenléte megkönnyíti erôs kapcsolatok kialakítását fóként olyan emberek számára, akik egyébként magányosak vagy félénkek. Erôs és stabil kapcsolatok nagyobb valószínúséggel alakulnak ki olyan egyének között, akik hasonló érdeklődésúek, illetve akiket hasonló attitúdök jellemeznek. Az ilyen emberek köre korlátozott, de az internet lehetôvé teszi, hogy ezek nagyobb számban találjanak hozzájuk hasonló embereket, leküzdve a fizikai korlátokat. Az anonimitás legfontosabb szerepe abban áll, hogy online az emberek gyakran többet árulnak el magukról, ôszintébbek, és a kapcsolatokat nem terhelik meg olyan gátló, előítéletre okot adó tényezók, mint például a nemi vagy faji hovatartozás, a kor vagy a külsố megjelenés. Parks és Floyd (Parks-Floyd 1996) kutatási eredményei szerint az, hogy valaki kialakít-e online kapcsolatokat, nem elsôsorban a személyiségvonásai vagy demográfiai jellemzối alapján dól el, hanem sokkal inkább az e téren szerzett tapasztalatok függvényében. McKenna és szerzốtársai ezzel szemben azt mutatják ki, hogy a személyiségbeli jellemzók nagyban befolyásolják, hogy valaki mennyire nyílik meg és bontakozik ki az interneten (McKenna-Green-Gleason 2002). Megállapítják, hogy azok, akiknek kevesebb hagyományos kapcsolatuk van, illetve magányosak, nagyobb valószínúséggel alakítanak ki online kapcsolatokat.

\section{A blogok körül kialakuló online közösségek}

\section{Mennyisési adatok}

„A blogok olyan rendszeresen frissített honlapok, amelyeknek a tartalma meghatározott időközönként, fordított időrendi sorrendben jelenik meg” (Schmidt 2007). Az egyes közleményekhez az olvasók általában „kommenteket” fúzhetnek, és az egyes blogok gyakran tartalmaznak más blogokhoz vezetó linkeket. Az így kialakult rendszert nevezzük blogoszférának. A blogoszféra méretéról lehetetlen pontos információt adni, csak becslésekkel élhetünk: „A létező blogok pontos száma egy adott időpillanatban - a blogoszféra dinamikus és decentralizált jellegéból fakadóan - nem határozható meg. A blogok száma az elmúlt években rohamosan nốtt, bár a közelmúltban a növekedés üteme lassulni látszik." (Sifry 2007)

A magyarországi blogoszféra méretére vonatkozóan az ITTK (Információs Társadalom és Trendkutató Központ) panelvizsgálatából származó adatokat használtam fel 
(ITTK-NRC 2008). ${ }^{1}$ A felméréshez igénybe vett minta reprezentatív volt a Magyarországon lévô internetfelhasználók teljes populációjára nézve. A blogoszféra kiterjedésére a „Szokott-e ön blogot olvasni?” kérdésre adott válaszokból következtethetünk, melyeknek a megoszlását az 1 . ábra mutatja be.

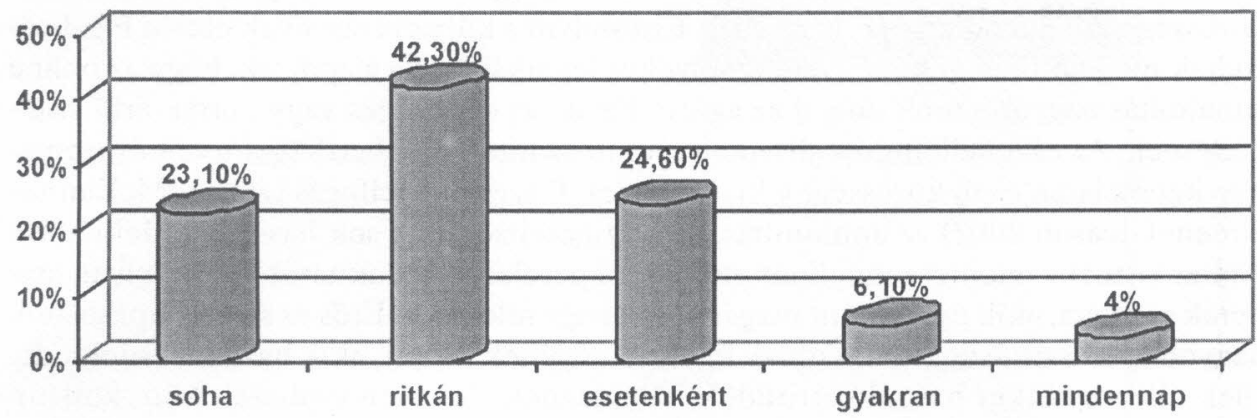

1. ábra

Szokott-e ön blogot olvasni?

(Forrás: ITTK-NRC 2008)

A minta körülbelül tíz százalékát alkotják azok, akik „meglehetôsen gyakran” vagy „rendszeresen” olvasnak blogokat, ami Magyarország internetfelhasználó népességére vetítve körülbelül 370000 embert jelent. ${ }^{2}$

A blogot író személyek számát az alábbi kérdés volt hivatott felderíteni: „Írt-e Ön az utóbbi egy hónapban blogbejegyzést?” A válaszok megoszlása a 2. ábrán látható.

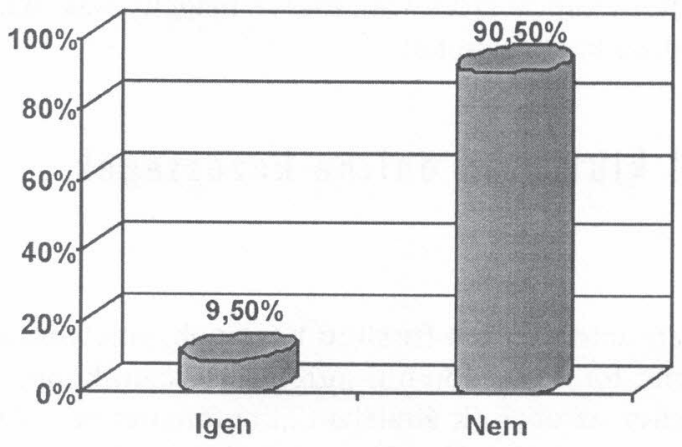

2. ábra

Írt-e Ön az utóbbi egy hónapban blogbejegyzést?

(Forrás: ITTK-NRC 2008)

\footnotetext{
${ }^{1}$ Az adatokat ezúton szeretném megköszönni Rab Árpádnak, az ITTKK kutatójának.

${ }^{2}$ Magyarországon 2007-ben körülbelül 3,7 millió fő használta az internetet.
} 
A válaszadók közel tíz százaléka írt blogbejegyzést az adott időszakban, aminek alapján Magyarországon közel 370 ezren blogolnak. Az eredmények értelmezésekor azonban figyelembe kell venni azt, hogy az ezer megkérdezettból összesen hétszázötvenen válaszoltak a blogírással kapcsolatos kérdésre.

\section{A blogközösségek korábbi vizsgálatai}

A szociológiai jellegú vizsgálatok közül kevés foglalkozik a blogoszféra leírásával és mechanizmusainak feltárásával. A tudományos igényú kutatások némelyike az itt kialakuló hálózatok strukturális vizsgálatára törekszik, olyan témákra koncentrálva, mint például az információáramlás a blogoszférában (Adar-Adamic 2005, Herring et al. 2005). Ezek a vizsgálatok elsốsorban a hálózatelméleti gondolkodást alkalmazzák a blogoszférára.

Egy másik kutatási irányzat az ún. strukturációs elmélet (sociological structuration theory) megközelítésével vizsgálja a blogokat. E szerint az elmélet szerint minden társadalmi cselekedetet „a struktúra és a képviselet kettôssége” határozza meg (Giddens 1984). A blogokra alkalmazva az elméletet: a blogger egy meghatározott szoftvert használ meghatározott kommunikációs cél elérésére. Három kiemelendő strukturális elem különböztethetố meg: a szabályok, a kapcsolatok és a kód (Schmidt 2007). Az elmélet alapján végzett kutatások szerint egyes blogközösségeknek eltérố procedurális szabályaik vannak, amelyek önmagukban a kapcsolatok mértékére utalnak. Csak azok tekinthetók a közösség tagjainak, és azok tudják kommunikációs céljaikat elérni, akik ezeket a szabályokat ismerik és követik (Wei 2004).

A kapcsolatok két fớ csoportja különböztethető meg: a blog tartalmába ágyazott hipertextkapcsolatok (digitális linkek), amelyek honlapokat kötnek össze, valamint a szociális kapcsolatok, amelyek a blogok szerzối között jöhetnek létre. A digitális linkek különféle szoftvermechanizmusok útján jönnek létre (permalink, trackback, kommentek), esetenként automatikusan, máskor a blogger aktív közremúködésével. Ezek a digitális linkek sokszor a társas kapcsolatok jegyeit is magukon viselik, hiszen lehetséges, hogy a blog szerzójével egyezố vagy eltérô vélemény kifejezésre juttatása jelenik meg bennük. Hálózatelméleti megközelítéssel nézve mikroszinten az egyének bizonyos forrásokra irányítják a figyelmet a digitális linkek és a kommentek által, amelyek így a szúrés és felerősítés funkcióit látják el. Makroszinten a linkek és kommentek hálózatos struktúrát eredményeznek, amelyet az „erôtörvény” (power law) jellemez.

Egyes kutatók a blogoszférát az egyéni vélemények, gondolatok közlésének színtereként és azon túl az online közösségek kialakulására módot adó területként értékelik, ahol hasonló érdeklődésú egyénekból álló csoportok kialakulására és fenntartására van lehetôség (Wei 2004).

Fontos megjegyezni, hogy nem minden virtuális csoport alkot virtuális közösséget. Anita Blanchard egy erre vonatkozóan végzett kutatásának ismertetését a virtuális közösségek ismérveinek összefoglalásával kezdi (Blanchard 2004). Szerinte először azokat a virtuális helyeket kell azonosítani, ahol az egyének kapcsolatba léphetnek egymással: ezek az ún. virtuális telepek, amelyeken belül léteznek a virtuális közösségek. 
Arra keresi a választ, hogy a blogoszférán belül mozgó egyének halmazai jellemezhetók-e közösségként. Végeredményben arra a megállapításra jut, hogy a blogok körül kialakuló csoportok szigorúan véve nem tekinthetốk virtuális közösségnek, csak bizonyos aktív olvasók, ,kommentezók” szúk köréról beszélhetünk (uo.).

Anjo Anjewierden és Lilia Efimova a közösség nyomainak felderítésével foglalkozó cikkükben (Anjewierden-Efimova, 2006) eszközkészletet ajánlanak az olvasóknak a blogok átfogó vizsgálatához. Véleményük szerint egyre több forrás támasztja alá, hogy a blogok körül szociális struktúrák alakulnak ki, s ezek hatással vannak a blogolás normáira és gyakorlatára. A blogkutatást a régészeti kutatásokhoz hasonlítják abból a meggondolásból, hogy a közösség tagjai ún. digitális nyomokat hagynak maguk után, amelyek gyakran közösségük meghatározó jegyei.

A blogközösségek kutatásának egy újabb megközelítése Nancy White-tól származik, aki a blogközösségek három olyan típusát azonosítja, amelyek - véleménye szerint a leggyakrabban fordulnak elő a blogoszférában (White 2006). Elsóként a blogcentrikus közösséget emeli ki, ami egy személy, egy szervezet vagy egy ügy blogja körül alakul ki. Magához vonzza az embereket, akik végül a közösséget alkotják, melynek kifejlődésében meghatározó szerepet játszanak a fó „,kommentelók”, akik további olvasókat is vonzanak az oldalra. A második típust a témacentrikus közösségek alkotják, amelyekre az jellemzô, hogy közös témával foglalkozó blogok között jönnek létre. (Ilyen téma lehet pl. az étkezés, a kismamaság, a politika, az utazás stb.). Ahogy ezek növekednek, egyre inkább hálózatos jellegúvé válnak, és a hálózaton belül egy-egy specifikus témában újabb közösségek formálódhatnak. Végül a harmadik típusba a közösségcentrikus blogközösségeket sorolja, amelyek egy meghatározott platformon múködő bloggerek és blogolvasók összességét foglalják magukban. Az ilyen, gyakran regisztrációs követelménnyel védett közösségek tagjai közelebb állnak egymáshoz, mint az elôzó két típusban. Ezekben a közösségekben kisebb hangsúlyt fektetnek a digitális linkekre, fontosabb, hogy ki kinek a blogján „,kommentezik”.

\section{A zenei blogok vizsgálata}

\section{Kérdések}

Kérdéses volt számomra, hogy létezik-e hálózat a bloggerek között, azaz a vizsgált blogok közösségeiben kialakulnak-e a hálózati funkciók. Megvizsgáltam a hálózat jellemzóit, struktúráját és kiterjedését. A kutatás elsôsorban a bloggerek között létrejövố társas kapcsolatokra és bloggerek által alkotott online közösségek múködésére irányult: arra voltam kíváncsi, hogy ezek valóban virtuális közösséggé formálódnak-e, és ha igen, annak más virtuális közösségekhez viszonyítva milyen sajátosságai vannak. A kutatás fő kérdései tehát a következók voltak:

1. Kialakul-e hálózat a blogok, illetve a bloggerek között?

2. Amennyiben létrejön, az milyen jellemzókkel írható le?

3. Létezik-e a virtuális közösség valamilyen formája a hálózaton belül?

4. Amennyiben igen, az milyen jellemzókkel írható le? 


\section{Kutatási módszerek}

A kutatás célja bizonyos típusú online közösségek vizsgálata, s ezen belül az internetes blogok és bloggerek közötti kapcsolatokra vonatkozó következtetések megfogalmazása volt, ám a fenti kérdések megválaszolásának lehetôségét önmagában egyetlen különálló vizsgálati módszer sem tette lehetôvé. Ezért olyan átfogó és összetett elemzési technikát választottam, amely áthidalja a kérdések összetettségéból fakadó problémákat, és alkalmas a blogok és bloggerek közötti kapcsolatok, valamint a blogokból felépülő hálózat együttes feltérképezésére.

Mindenekelốtt szükség volt a vizsgált blogok közötti digitális kapcsolatok (URL linkek) összegyúitésére. Mérnem kellett továbbá a blogok közötti kapcsolatok egy másik megnyilvánulási formáját, a „kommentek” számát és irányát is, hogy feltérképezhessem az egyes blogok szerzóitől származó, más blogokon publikált tartalmak megjelenését. Ezenkívül meg kellett ismernem a blogok szerzóinek a többi blog szerzóihez fü:ödö kapcsolatait is, amihez online kérdőives módszert alkalmaztam: a kérdőívet a mintában szerepló bloggerek közül kilencen töltötték ki. ${ }^{3}$ A megkérdezetteknek a mintába került többi bloggerre vonatkozóan meg kellett határozniuk a közöttük fennálló társas kapcsolat minőségét, a válaszlehetôségek közül választva mind a személyes, mind a virtuális ismeretség minôségére vonatkozóan:

- „Személyes ismeretség: 1. nem, 2. arcról, 3. dumáltunk már, 4. találkozáskor dumálunk, 5. rendszeresen találkozunk, 6. barátom/barátnőm.”

- „Virtuális ismeretség: 1. nem, 2. névról ismerôs, 3. blogját ismerem, 4. blogját olvasom, 5 . volt privát kommunikáció köztünk, ${ }^{4} 6$. rendszeres privát kommunikáció, 7. online projektünk van."

A kérdôívben arra a kérdésre is válaszolniuk kellett a bloggereknek, hogy a mintában szereplő többi bloggert saját blogjának írása előtt vagy azután ismerte-e meg, és ismerkedésük milyen formában történt:

• „Blogom írása elốtt: 1 . ismertem személyesen, 2. ismertem virtuálisan, ${ }^{5}$ 3. nem ismertem."

- „Blogom írása után: 1. ismertem személyesen, 2. ismertem virtuálisan, 3. nem ismertem."

Végül fel kellett térképeznem a bloggereknek a blogolással kapcsolatos normáit és attitûdjeit, és meg kellett ismernem a többi bloggerhez fúződő kapcsolataik jelentését és jelentőségét is. Ehhez mélyinterjúkat folytattam az egyes blogok tulaj-

\footnotetext{
${ }^{3}$ Good bye Paris, Alice, Sam Spade, Mizeka, Söcsö, Csoo-Gurkaserpa (egynek számítva), Rolo, Stereomaci, Vegyeskazetta.

${ }^{4}$ A privát kommunikáció rendszeres kommentezést vagy a két blogger közötti e-mail váltást jelentett.

${ }^{5}$ Ebben az esetben a virtuális ismeretséget az alábbi leírással határoztam meg, ami a kérdő́ivben is olvasható volt: „Privát üzenetet váltottatok korábban, vagy rendszeresen olvasod és kommentezed a blogját?"
} 
donosaival. Az interjúk online formában, szöveges üzenetek váltásával (chat keretében) készültek, és átlagosan egy órát vettek igénybe. A beszélgetésekhez elôre elkészítettem egy kérdésvázlatot, az alábbi logikát követve: Bevezetô, 1. blokk: a blogger viszonya a saját blogjához, 2. blokk: a blogolással kapcsolatos általános vélekedése, 3. blokk: a „bloggerek mint közösség” szemlélettel kapcsolatos vélekedése, 4. blokk: zárás.

\section{Mintavétel}

A mintába kerülő blogok kiválasztásának az első kritériuma az volt, hogy a blogok egy témáról szóljanak (popzene). Az elemzés kivitelezhetôségét szem előtt tarva további feltételem volt, hogy magyar nyelvúek legyenek, hogy a három jelentốs magyarországi blogszolgáltató egyikén legyenek regisztrálva, és természetes személyhez tartozzanak, vagyis ne legyen intézményi hátterük.

A második lépés a vizsgálandó blogok konkrét kiválasztása volt. Itt azt tartottam szem elő́tt, hogy a bloghálózat magában hordozza az online közösség kialakulásának lehetôségét. Ezért egy tetszólegesen kiválasztott blog linkjeiból kiválasztottam azokat, melyek megfeleltek a fenti kritériumoknak, és így egy összesen 15 elemból álló mintát alakítottam ki a kutatás számára. Végeredményben tehát a teljes magyar bloghálózat egy kiválasztott alcsoportján belül, egy feltételezett központ köré szerveződő bloghalmazból nyertem a mintámat, melyet a következő blogok alkottak:

\begin{tabular}{|c|c|c|c|}
\hline & Blog neve & Blog szerzól(i) & $B \log U R L$ \\
\hline 1 & 16 maybe less & Ursula & www.16maybeless.freeblog.hu \\
\hline 2 & diagram & Diagramm & www.diagram.freeblog.hu \\
\hline 3 & good bye paris & Goodbeyparis & www.goodbyeparis.blog.hu \\
\hline 4 & hello stranger & Alice & www.hellostranger.blog.hu \\
\hline 5 & lemezek nektek & Lemezek nektek & www.lemezeknektek.freeblog.hu \\
\hline 6 & mai zene & Sam spde & www.maizene.freeblog.hu \\
\hline 7 & minden zenében kanál & Mizcka & www.mizeka.blog.hu \\
\hline 8 & music is my radar & Söcsö & www.musicismyradar.blog.hu \\
\hline 9 & new kids on tge blog & Csoo, Gurkaserpa & www.newkidsontheblog.blog.hu \\
\hline 10 & oriasi & Rolo, Zsenya, Toszi & www.oriasi.blog.hu \\
\hline 11 & popcorner & Popcorner & www.popcorner.blog.hu \\
\hline 12 & $\begin{array}{l}\text { things you don't have to } \\
\text { know about music }\end{array}$ & Megmondó & http://rakenrol.blog.hu/ \\
\hline 13 & sofa king & Vargyai & http://lets-have-a-war.blogspot.com/ \\
\hline 14 & stercomackó & Stereomacko & http://stereomacko.blog.hu/ \\
\hline 15 & vegyeskazetta & Vegyeskazetta & http://vegyeskazetta.blog.hu/ \\
\hline
\end{tabular}




\section{A vizsgálat eredményei}

\section{A blogok közötti digitális kapcsolatok}

Az elsó feladat a blogok közötti digitális linkek révén létrejövố hálózat feltérképezése volt. Ennek az volt a célja, hogy kiderítsem, létezik-e egyáltalán valamiféle hálózat a vizsgált blogok között, és amennyiben igen, annak melyek a jellemzók.

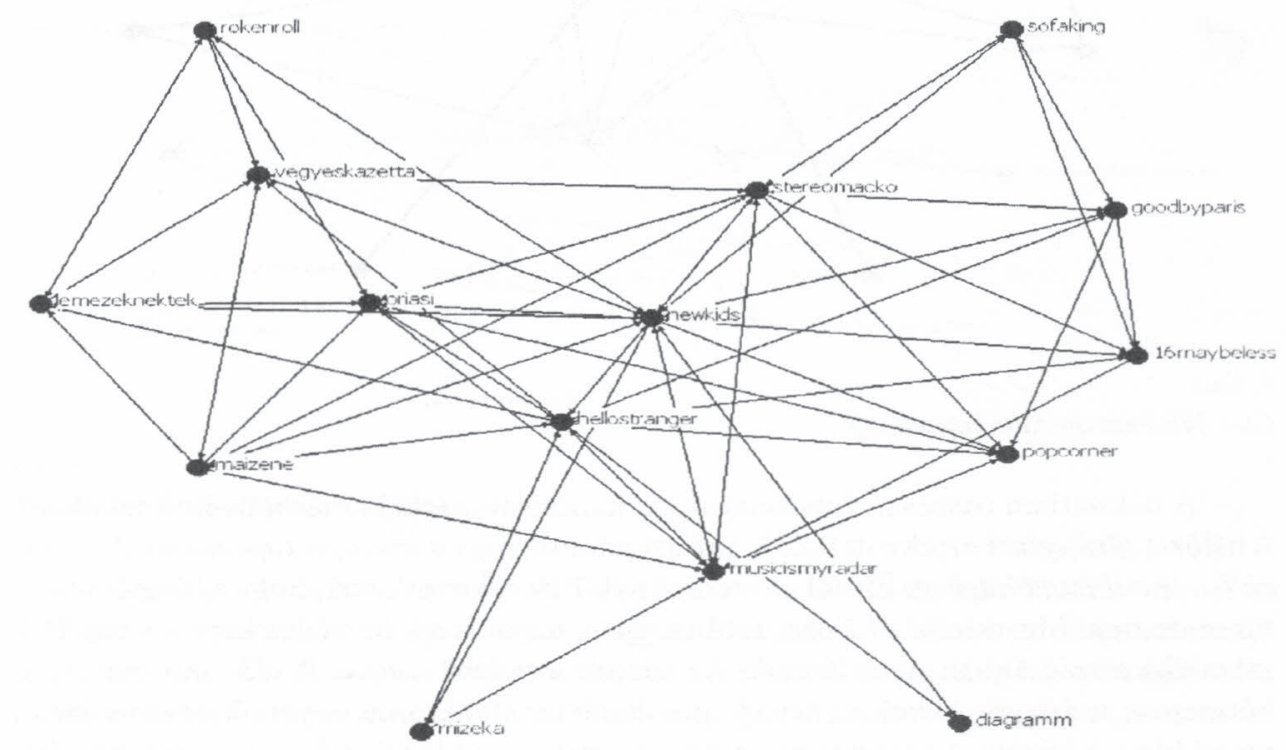

3. ábra

A vizsgált blogok közötti digitális kapcsolatok gráfja

A gráfon kirajzolódó hálózatban összesen 75 relációs kapcsolat található, azaz 75 link mutat valamelyik blogból egy másikra. A hálózat sürüségének értéke 0,357 , ami azt jelenti, hogy a lehetséges kapcsolatok 35,7 százaléka létezik a valóságban. Ebból az is következik, hogy a blogok jelentốs része nem hivatkozik a hálózat többi tagjára, ugyanis a lehetséges kapcsolatok 64,3 százaléka a valóságban nem létezik. Az adatok standard szórása 0,479 , ami majdnem másfélszerese az átlagértéknek, tehát a kapcsolatok eléggé egyenlótlenül oszlanak meg a blogok között.

Amennyiben két blog között csak a kölcsönös egymásra hivatkozást tekintjük kapcsolatnak, az adatok alapján az alábbi gráf rajzolható fel: 


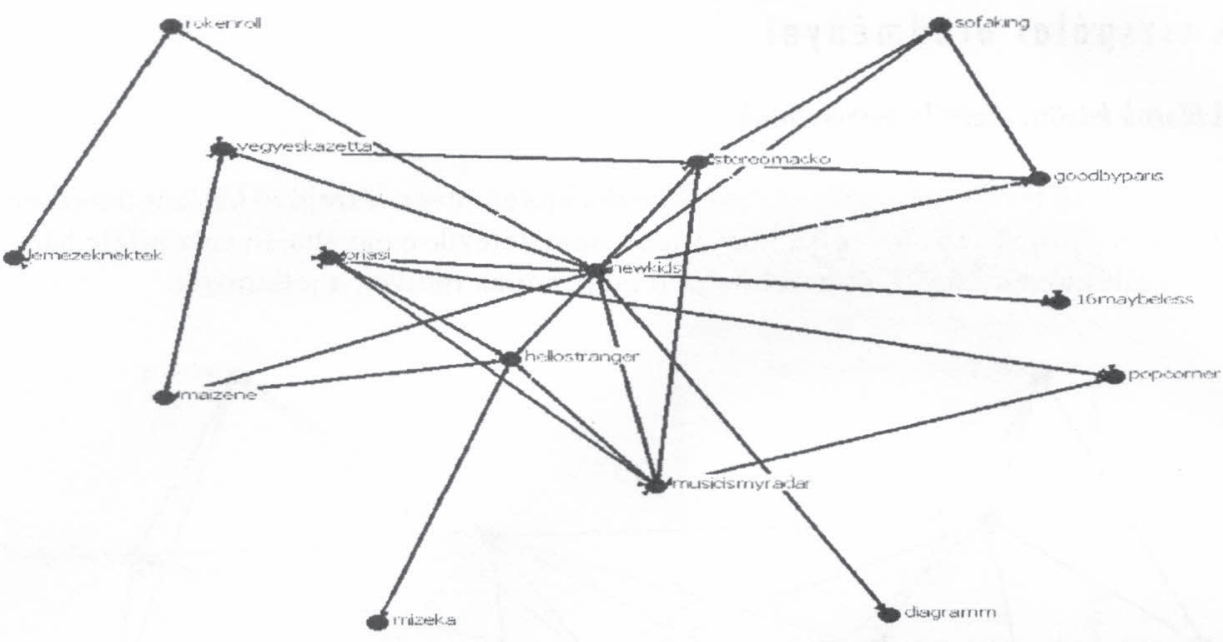

4. ábra

Csak kölcsönös digitális kapcsolatok

A hálózatban összesen huszonöt ilyen kapcsolatot jelző kölcsönös link található. A hálózat sürḯségének értéke itt 0,233, ami azt jelenti, hogy a lehetséges kapcsolatok 23,3 százaléka létezik a valóságban. Ebból az eredményból az is következik, hogy a blogok jelentốs része nem hivatkozik a hálózat többi tagjára, ugyanis a lehetséges kapcsolatok 76,7 százaléka a valóságban nem létezik. Az adatok standard szórása 0,423, ami majdnem kétszerese az átlagértéknek, tehát a kapcsolatok meglehetôsen egyenloótlenül oszlanak meg a blogok között. A valóságban ez azt jelenti, hogy a blogoknak csak egy részére jellemzố az egymásra hivatkozás.

A digitális linkeket tekinthetjük bizonyos ajánlásnak vagy minôségbiztosításnak is, amit a blog szerkesztôje tartalomként helyez el a saját oldalán. Ezzel azt üzeni olvasóinak, hogy „,ha engem olvastok, olvassátok ezeket is, mert jók”. A jó minősítés kétféleképpen értelmezhetố: 1. „én is olvasom”; 2 . „ez a blog olyan, mint az enyém”. Természetesen e kettố kombinációja is elképzelhetô, ám bármelyik elegendô lehet önmagában is ahhoz, hogy ajánlásként funkcionáljon egy blogger honlapján. Mindez azt is jelenti, hogy a milliónyi weboldal közül a blogger csak néhányat ajánl látogatói számára, ebból pedig az következik, hogy a blogok közötti digitális kapcsolatok alkalmasak a hálózat szuíró funkciójának ellátására.

Másfelól a digitális kapcsolatok lehetôséget adnak arra, hogy a különbözố látogatókat azonos irányokba tereljék, figyelmüket azonos területre összpontosítsák. Amennyiben link mutat egy internetes oldalra, nő annak a valószínúsége, hogy oda eljut egy felhasználó. A linkek segítségével közös platformra lehet irányítani különböző emberek figyelmét és aktivitását.

A kutatás eredményei alapján azt állíthatjuk, hogy a vizsgált blogok esetében adott volt a blogok közötti hálózat létrejöttének két szükséges feltétele: a linkek betöltötték a szürés és az „összehozás” funkcióját. 


\section{A, ,kommentek” révén létrejövố kapcsolatok}

A kommentek aszimmetrikus kapcsolatként való megjelenítésével a következố gráf rajzolható fel az adatmátrixból:

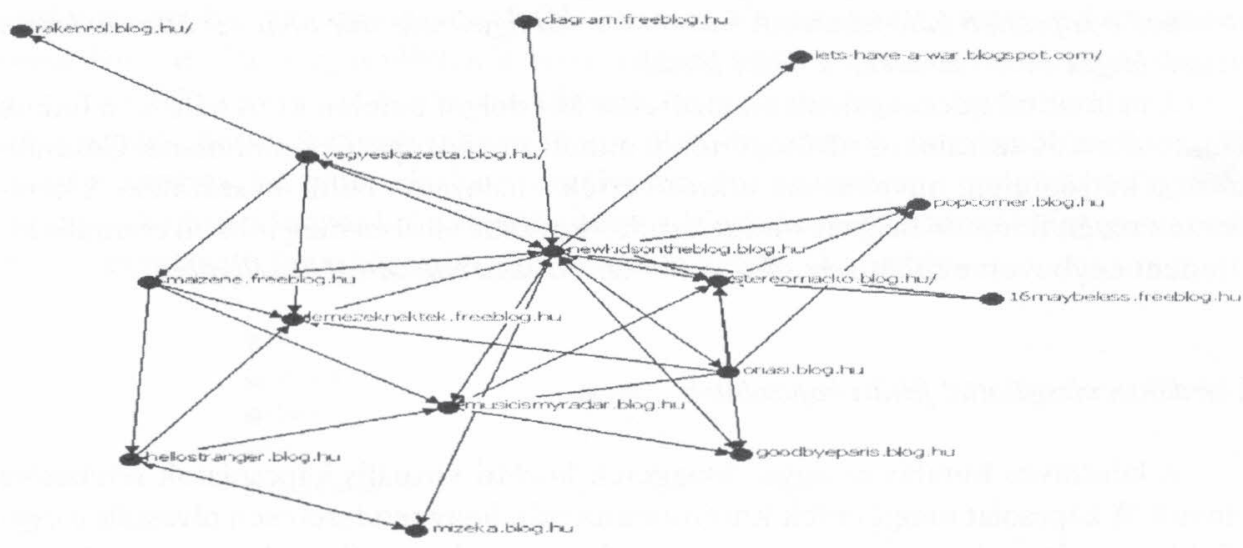

5. ábra

A kommentek révén létrejövó kapcsolatok

Ebben a hálózatban összesen 41 ilyen kapcsolat található, azaz 41 alkalommal írt kommentet valamelyik blogger valaki másnak a blogjába. A hálózat sürüségének értéke 0,195, ami azt jelenti, hogy a lehetséges kapcsolatok 19,5 százaléka létezik a valóságban. Ez egyszersmind annyit jelent, hogy a bloggerek igen kevés más blogban „kommenteznek", ugyanis a lehetséges kapcsolatok 80,5 százaléka a valóságban nem létezik. Az adatok standard szórása 0,396 , ami itt is majdnem kétszerese az átlagértéknek, tehát a kapcsolatok eléggé egyenlótlenül oszlanak meg a blogok között. A valóságban ez azt jelenti, hogy a bloggerek egy része hajlamos „kommentezni” más blogokban, míg mások ezt jóval ritkábban teszik meg.

A „kommentezés” alapján létrejövő kapcsolatok sûrúségéból először is a hálózat felerốsítố funkciójára következtethetünk, mivel a komment megírása bizonyos jelzés a többi látogató számára egy adott téma relevanciájáról. A másik oldalról megközelítve a kérdést azt mondhatjuk, hogy a látogatók nagyobb valószínúséggel fognak kommenteket fúzni azokhoz a témákhoz, amelyek relevánsabbak számukra. ${ }^{6}$ Ebból az következik, hogy a kommentezés az adott bejegyzések relevanciája alapján afféle kapcsolaterösitốszerepet tölt be a blogok között.

A kommentezés még egy további fontos szerepet is betölt a bloggerek közötti kommunikációban és a kapcsolatok kialakításában: a kommentek lehetôséget adnak az egyes kommentezók számára, hogy valamilyen formában kapcsolatba lépjenek más

${ }^{6}$ Ezt erôsítik az interjúkban a kommentezés kiváltó okaira vonatkozó kérdésekre adott válaszok is. A leggyakoribb válasz a bloggerek részéról az volt, hogy akkor kommenteznek, ha egy cikk felkeltette az érdeklődésüket, vagy valamilyen formában érdekesnek, izgalmasnak tartják azt. 
kommentezókkel. Erre utalnak a virtuális kapcsolatok és a kommentezés összefüggésére vonatkozó eredmények: a kétféle hálózat közötti korrelációs együttható 0,7-es értéke erôs kapcsolatról tanúskodik. Ebból arra következtethetünk, hogy a vizsgált bloggerek esetében a kommentezés erôsítette a közösség kialakulásának lehetôségét.

Az eredmények ast mutatják, hogy mind a digitális linkek, mind a kommentek tekintetében tételezhetố a kapcsolati háló létezése. A fentebbi érvelést figyelembe véve tehát ast állitom, hogy a vizsgált blogok között kialakult hálózat létezik.

A hálózat tulajdonságainak elemzésekor két dolgot emelek ki. A hálózat a linkek tekintetében 36 százalékos súrúségértéket mutat, ami közepesnek mondható. Centralizáltsága kétségtelen, mivel az ezt tükrözó érték a hálózaton belül 46 százalék. A kommentek révén felépülő́ hálózat - mint láttuk - kevésbé sưrú és még inkább centralizált. Mindent egybevetve tehát nem sürü, erốsen centralizált hálózatról beszélhetünk. ${ }^{7}$

\section{A kérdớves vizsgálattal feltárt kapcsolatok}

A kérdốives kutatás az egyes bloggerek közötti virtuális kapcsolatok feltárására irányult. A kapcsolat meglétének kritériuma az volt, hogy rendszeresen olvassák-e egymás blogjait, és azokon kommenteznek-e, valamint az, hogy váltottak-e már privát üzeneteket egymással. Csak azokat a kapcsolatokat tekintettem létezóknek, amelyeknek a meglétét mind a két fél megerósítette. Az adatok feldolgozását követôen az alábbi gráfot kaptam:

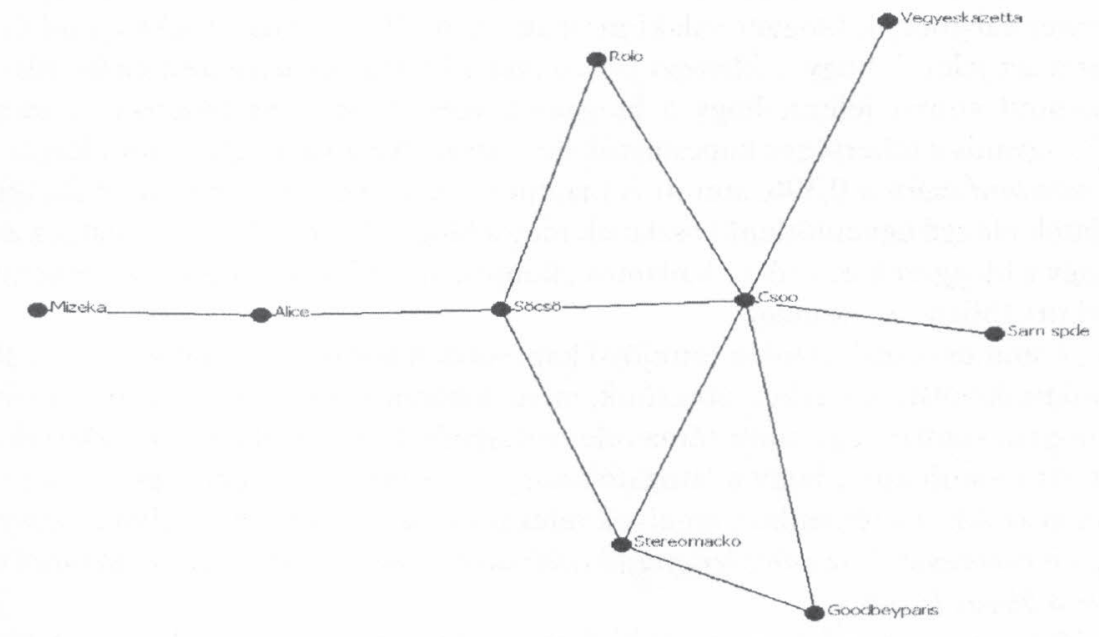

6. ábra

Visszaigazolt virtuális kapcsolatok

${ }^{7}$ Feltételezésem szerint a hálózatra vonatkozó mutatók hasonlóan alakultak volna, ha a mintavételi eljáráskor más blogok kerültek volna a mintába, ám az egyes blogokra vonatkozó mutatószámok bizonyára másnak adódtak volna. 
A hálózatban összesen 11 kapcsolat található, azaz a nyolc blogger között 11 alkalommal jött létre mind a két oldalról virtuális kapcsolat. A hálózat sürüség értéke 0,306, ami azt jelenti, hogy a lehetséges kapcsolatoknak köruilbelïl a 30 százaléka létezik a valóságban. A bloggerek jelentôs része tehát nem áll kapcsolatban a hálózat többi tagjával, ugyanis a lehetséges kapcsolatok 70 százaléka a valóságban nem létezik. Az adatok standard szórása 0,461 , ami majdnem másfélszerese az átlagértéknek, vagyis az ilyen jellegú kapcsolatok is eléggé egyenlótlenül oszlanak meg a bloggerek között.

A kérdőív egy másik kérdése azt firtatta, hogy a blogolás milyen hatással van a virtuális ismerkedésre. A bloggereknek meg kellett mondaniuk, hogy mielő́tt ók maguk blogolni kezdtek, kit ismertek akár személyesen, akár virtuálisan a mintába került többi blogger közül. A válaszokból kiderült, hogy a blogolás megkezdése elốtt igen kevés ilyen kapcsolat állt fenn közöttük. Ezt az alábbi gráf is jól mutatja:

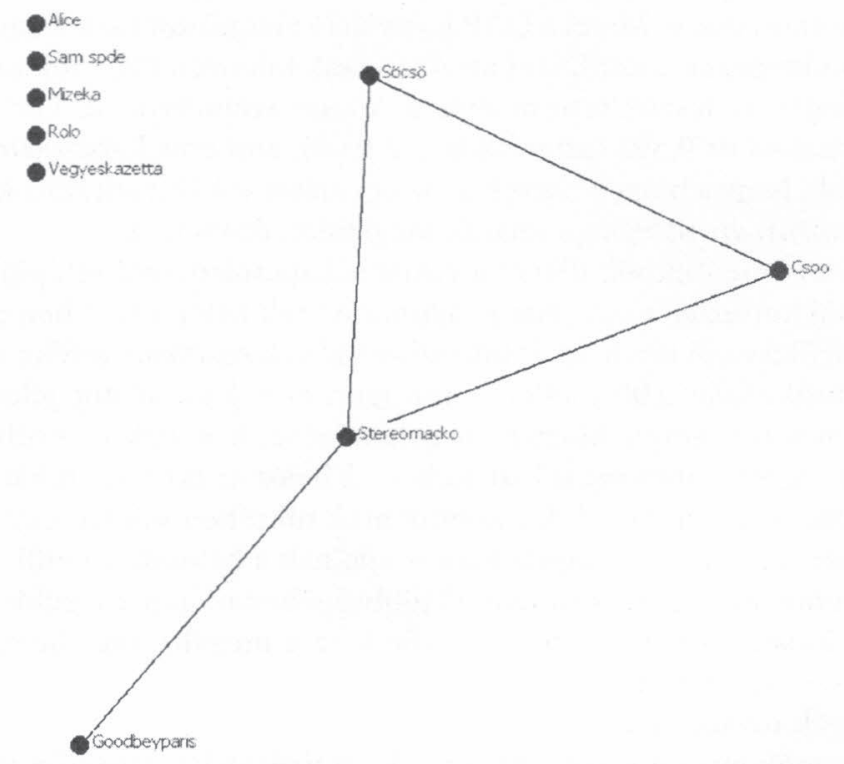

7. ábra

Virtuális kapcsolatok a blogolás megkezdése elótt

A 6. és a 7. ábra összevetésével jól látható a blogolás előtt és az azt követően létrejött virtuális kapcsolatok arányában mutatkozó különbség. Megállapíthatjuk, hogy $a$ blogolás elósegíti a virtuális kapcsolatok kialakulását, ami a virtuális közösség létének egyik szükséges feltétele.

A virtuális kapcsolati hálózat sürüsége alacsonynak mondható (30 százalék), ugyanakkor a hálózatot nagyfokú centralitás jellemzi (50 százalék), vagyis a hálózat tagjai laza, centralizált közösséget alkothatnak. Ám a kapcsolati hálózatok megléte önmagában még nem elégséges feltétele annak, hogy a bloggerek közösségének létezését feltételezzük. Mielő́tt a közösség létének vizsgálatát bemutatnám, érdemes egy rövid kitérố erejéig összehasonlítani az eddig megismert hálózatokat. 


\section{QAP korrelációs vizsgálat}

A különböző kapcsolatok alapján felépülő hálózatok közötti hasonlóságok, illetve eltérések feltárásához az ún. QAP korrelációs vizsgálatot alkalmaztam.

Először a digitális linkek, illetve a kommentek alapján felrajzolt hálózatok közötti hasonlóságot vizsgáltam. Az adatok számítógépes feldolgozása alapján a kétféle hálózat közötti korrelációs egyïttható értéke 0,485 (szignifikancia: 0,00 érték mellett), ami közepes erósségü kapcsolatra enged következtetni. A blogok közötti linkek és kommentek által létrehozott hálózatokban az egyes szereplók hasonló helyet foglalnak el. Ez arra utal, hogy akik a saját blogjukban hivatkoznak mások blogjaira, azok gyakrabban kommenteznek is a hivatkozott blogban, vagy fordítva: a mások blogjában kommentezó bloggerek gyakrabban jelenítik meg saját blogjukban a más blogokra vezetó linkeket.

Másodszor a digitális linkekból, illetve a virtuális kapcsolatokból származó hálózatokat hasonlítottam össze. Mivel a QAP korreláció vizsgálatot csak azonos méretú hálózatokon lehet elvégezni, a kérdôívet azonban csak kilencen töltötték ki, a linkeket tartalmazó hálózatot is leszúkítettem erre a kilenc személyre. A két hálózat közötti korrelációs együttható itt 0,593 (szignifikancia: 0,00), ami erốs kapcsolatot jelent, vagyis azt mondhatjuk, hogy a blogok esetében az egymásra való hivatkozások erősen utalnak a bloggerek közötti virtuális kapcsolatok meglétére, és viszont.

Végül a kommentekból, illetve a virtuális kapcsolatokból felépülő hálózatok közötti statisztikai korrelációt vizsgáltam, a kommentek hálózatát ebben az esetben is kilencelemúre szúkítve. A két hálózat közötti korrelációs együttható értéke ekkor 0,706-nak adódott (szignifikancia: 0.00 mellett), ami igen erôs kapcsolatot jelent: a bloggerek kommentjei más bloggerek blogjain nagyban növelik annak az esélyét, hogy a két blogger között egyéb kapcsolat is kialakuljon. A hálózati aktivitás tehát közösséget hoz létre, mivel azok a szereplók, akik a kommentek tükrében sok kapcsolattal rendelkeznek, jellemzően sok virtuális kapcsolatot is ápolnak a hálózaton belül. Feltételezhetô, hogy a kommentezés az esetek túlnyomó többségében idóben megelőzi a virtuális kapcsolatok kialakulását, így plauzibilisnek tûnik az a megállapítás, hogy a kettő között ok-okozati összefüggés áll fenn.

Az interjúk további tanulságai

A kilenc mélyinterjú során a bloggerek motivációjára, attitúdjeire, valamint egymás közti kapcsolataira vonatkozóan feltárt adalékok bemutatása meghaladná e cikk terjedelmi kereteit, ezért itt az idézetek melloozésével csak összefoglalóan jelzem, hogy a bloggereket elsósorban a szabad önkifejezés vágya motiválja a blog indítására. Indítékaik között a baráti köriik számára nyújtott információközlés igénye mellett fontos szerepet játszik az a szándék, hogy izlésformáló hatást fejtsenek ki tágabb környezetiikre is.

A kapcsolatépités tekintetében jellemzố rájuk az az igény, hogy megnyilatkozásaikra hozzájuk hasonló érdeklődésú emberektốl kapjanak visszajelzéseket vagy inspiráló gondolatokat. Az így kialakuló virtuális kapcsolatokat azonban a személyes kapcsolatokhoz mérve sekélyesebbnek minôsítik.

A mintában szereplő blogok többsége tartalmilag egy bizonyos rétegízlést képvisel, amire az újító attitûd jellemző, legalábbis hazai viszonylatban. A bloggerek figyelnek egymásra, sokat számítanak nekik a visszajelzések. Közösségteremtô eróként összefúzi óket egymással, hogy zenei ízlésüket tükrözố blogjaik tartalmilag nagyon ha- 
sonlók. Bizonyos közös normarendszer meglétére ebben a körben egyedül a mainstream zenei izlés jellegzetesen visszatéró elutasitása utal, ugyanakkor az egymás iránti kölcsönös bizalom kétségkívül fennáll. Amennyiben tehát elfogadjuk, hogy a vizsgált bloghálózaton belül létezik valamiféle közösség, hozzá kell tennünk, hogy ez nagymértékben különbözik nemcsak a hagyományos közösségektól, hanem a más típusú virtuális közösségektôl is.

\section{Összegzés}

A vizsgálat eredményei a következókben foglalhatók össze:

- létezik a blogok és a bloggerek hálózata,

- ez laza, centralizált hálózat,

- a hálózat tagjai között létrejött a társas kapcsolatok bizonyos formája, ami a közösség kialakulásának szükséges feltétele,

- a bloggerek között létezik egy bizonyos fajta virtuális közösség, melynek jellemzói ○ a közös motívumok, célok és attitúdök,

○ a bizalom a csoport tagjai között, továbbá

- a csoporton belüli kommunikáció,

- ám ez a közösség eltér a „hagyományosabb” virtuális közösségektól az alábbi vonások tekintetében:

○ a közösségre vonatkozó normák nem egyértelmúek,

○ a normák fenntartására szolgáló mechanizmusok nem azonosíthatók.

Az eredmények a minta méretéból fakadóan magára a vizsgált közösségre értendók. Éppen ezért érdemesnek tartanám hasonló vizsgálatok elvégzését más témájú bogokon is. A hálózatok kialakulásának elemzésekor fontos információkkal szolgálhatna továbbá a viszonyok idóbeli változásainak figyelembevétele is.

Kérdéses volt számomra, hogy a blogoszféra vizsgált szeletén belül az online közösség hiányával vagy pedig a közösség egy új formájával találkozunk-e. Bebizonyosodott, hogy a blogolás virtuális kapcsolatokat hoz létre azonos érdeklődésú, motivációjú emberek között, ami lehetôvé teszi a virtuális közösségek kialakulását. Véleményem szerint a kutatás során sikerült azonosítani a mintában a blogoszféra általánosan jellemzố vonásait, amelyek elsôsorban a blogközösségek sajátjai. Ezek arra mutatnak, hogy a bloggerek más online közösségeknél általában lazább kötôdésú, individualistább közösségeket alkotnak a világhálón.

\section{Irodalom}

Adar, E. - Adamic, L. A. 2005. Tracking information epidemics in blogspace. Proceedings of the 2005 IEEE/WIC/ACM International Conference on Web Intelligence, 207-214.

Anjewierden, A. - Efimova, L. 2006. Understanding weblog communities through digital traces. In On the Move to Meaningful Internet Systems 2006: OTM 2006 Workshops. Heidelberg, Springer Berlin, 279-289. 
Berry, W. 1993. Sex, economy, freedom, and community. New York, Pantheon.

Blanchard, A. 2004. Into the blogosphre. Retrieved április 2008, from http://blog.lib.umn.edu/: http://blog.lib.umn.edu/blogosphere/blogs_as_virtual.html

Dennis, A. R. - Pootheri, S. K. - Natarajan, V. L. 1998. Lessons from the early adopters of Web groupware. Journal of Management Information Systems, 14 (4), 65-86.

Efimova, L. 2004, Június. Weblog networks as social ecosystems. Retrieved április 2008, from mathemagenic: http://blog.mathemagenic.com/2004/06/10.html\#a1235

Figallo, C. 1998. Hosting Web communities: Building relationships, increasing customer loyalty, and maintaining a competitive edge. New York, John Wiley \& Sons.

Giddens, A. 1984. The Constitution of Society. Cambridge, Polity Press.

Herring, S. C. - Kouper, I. - Paolillo, J. C. - Scheidt, L. A. - Tyworth, M. - Welsch, P. -Wright, B. Ning Yu 2005. Conversations in the blogosphere: An analysis 'from the bottom up'. Proceedings of the Thirty-Eighth Hawaii International Conference on System Sciences.

Hiltz, S. R. 1984. On-line communities: A case study of the office of the future. Norwood, NJ, Ablex Publishing Corporation.

Hiltz, S. R. - Wellman, B. 1997. Asynchronous learning networks as a virtual classroom. Communications of the ACM, 40 (9), 44-49.

ITTK-NRC 2008. ITTK-NRC 2008.

Kollock, P. 1999. The Economies of On-line Cooperation: Gifts and Public goods in Cyberspace. In M. S. Kollock (ed.): Communities in Cyberspace. New York, Routledge.

Matzat, U. 2004. Cooperation and Community on the Internet: Past Issues and Present Perspectives for theoretical-empirical Internet Research. Analyse æ̋ Kritik, 26 (1), 63-90.

McKenna, K. Y. - Green, A. S. - Gleason, M. E. 2002. Relationship Formation on the Internet: What's the Big Attraction. Journal of Social Issues, 58 (1), 9-31.

Parks, M. - Floyd, K. 1996. Making Friends in Cyberspace. Journal of Communication, 00219916/96.

Rheingold, H. 1993. The virtual community: Homesteading on the electronic frontier. Reading, MA, Addison-Wesley.

Ridings, C. - Gefen, D. - Arinze, B. 2002. Some antecedents and effects of trust in virtual communities. Journal of Strategic Information Systems, 11 (3-4), 271-295.

Sassenberg, K. 2002. Common Bond and Common Identity Groups on the Internet. Group Dynamics, 6 (1), 27-37.

Schmidt, J. 2007. Blogging practices: An analytical framework. Journal of Computer-Mediated Communication, article 13.

Sifry, D. 2007, április. The state of the live web. Retrieved április 2008, from http://technorati.com/weblog/2007/04/328.html

Smith, A. D. 1999. Problems of conflict management in virtual communities. In Smith, M. A. - P. Kollock (eds.): Communities in cyberspace. New York, Routledge.

Stewart, D. 2005. Social status in an open-source community. American sociological review, 70 (55), 823-842.

Wei, C. 2004. Formation of norms in a blog community. In Gurak, S. A. (ed.): Into the Blogosphere. Rhetoric, Community, and Culture of Weblogs. from http://blog.lib.umn.edu/blogosphere/formation_of_norms.html

Wellman, B. - Gulia, M. 1999. Net Surfers Don't Ride Alone: Virtual Communities as Communities. In Wellman, Barry (ed.): Networks in the Global Village. Boulder, Westview Press.

White, N. (2006, július). Blogs and Community - Some thinking out loud. Retrieved április 2008, from www.fullcirc.com:

http://www.fullcirc.com/weblog/2006/07/blogs-and-community-some-thinking-out.htm 